\title{
A study on factors affecting job satisfaction of Telecommunication industries in Bangladesh
}

\author{
Ethica Tanjeen \\ Department of Business Administration, East West University, Bangladesh
}

\begin{abstract}
The purpose of this study is to examine the level of job satisfaction of employees in telecommunication industries in Bangladesh. Job satisfaction is the degree of favorableness towards his or her job. This paper discusses the factors that influence job satisfaction. These factors are working condition, job security, autonomy or freedom, relationship with colleagues, relationship with superior, promotion and pay. This research is done to explore the importance of factors that affects job satisfaction. Telecommunication sector is selected for this research as their business is running successfully in all aspects. This study is based on questionnaire method. A sample of 82 employees of different company's is taken to conduct this study. This paper explains various factors of job satisfaction from the perspective of employees in the selected telecommunication industries.
\end{abstract}

Keywords: Employee satisfaction, factors, job satisfaction, telecommunication industries.

\section{Introduction}

Job satisfaction is an indicator of how well a person is doing his or her job. Human resource management is a important aspects of an organization. Success and failure of an organization depends mostly on the performance of employees. Job satisfaction is obviously an important factor for all organizations. Companies must continuously improve employee satisfaction in order to stay profitable. Job satisfaction can be defined as an individual's general attitude toward his or her job. [1]. Price defined job satisfaction as the degree to which employees have a positive affective orientation towards employment by the organization. [2]

This study is generated from the consideration that job satisfaction is an important matter to bring employees more productive, innovative and committed. The problem statement for this study is to find out the factors that affect job satisfaction of employees in telecommunication sectors. The purpose of this study is to analyze job satisfaction. The telecommunication sector is chosen as the population for the study. Six companies are considered in this study. Total 82 employees are taken as the sample of this study. The study will focus on the following objectives:

- To determine the level of job satisfaction of employees

- demographics will be identified such as gender, age, length of services and salary to verify if they relate to job satisfaction.

\section{The industry}

\section{Literature Part}

The liberalization of Bangladesh's telecommunications sector began with small steps in 1989 with the issuance of a license to a private operator for the provision of inter alia cellular mobile services to compete with the previous monopoly provider of telecommunications services the Bangladesh Telegraph and Telephone Board (BTTB). Significant changes in the number of fixed and mobile services deployed in Bangladesh occurred in the late 1990s and the number of services in operation has subsequently grown exponentially in the past five years. The incentives both from government and public sectors have helped to grow this sector. It is now one of the biggest sectors of Bangladesh. As a populous country, its huge market has attracted many foreign investors to invest in this sector. The Telecom market in Bangladesh has differentiated characteristics of very low tele-density, inefficiency and totally controlled by capitalization. BTTB(Bangladesh Telephone and Telegraph Board) is proved to be incapable of providing sufficient interconnections to meet the demand of mobile services providers. The state owned BTTB has been the monopoly telephone service provider. The zest of improving the efficiency and ability of BTTB, the government initiated a restructuring program in telecom sector to corporative BTTB. In the telecom sector earth shaking changes cropped up when Bangladesh government allowed private sector participation in telecom sector by granting the permission to operate as a private service provider in 1989. 


\section{Job Satisfaction}

Job Satisfaction is simply how people feel about their jobs. It is the extent to which people like (satisfaction) or dislike (dissatisfaction) their jobs, it can also be a reflection of good treatment and an indicator of emotional well-being.

Spector refers to job satisfaction in terms of how people feel about their jobs and different aspects of their jobs. [3]. Schermerhorn defines job satisfaction as an affective or emotional response towards various aspects of an employee's work. Ellickson and Logsdon support this view by defining job satisfaction as the extent to which employees like their work. [4]. Abraham Maslow suggested that human needa from a five-level hierarchy ranging from physiological needs, safety, belongingess and love, esteem to self-actualization. [5]. Based on Maslow's theory, job satisfaction has been approached by some researchers from the perspective of need fulfillment (Kuhlen, 1963; Worf, 1970; Conrad et al., 1985)

Cranny et al. defined job satisfaction as an affective (emotional) reaction to a job that results from the incumbent's comparison of actual outcomes with those that are desired. [6].

Locke gives a comprehensive definition of job satisfaction as "a pleasurable or positive emotional estate resulting from the appraisal of one's job experience." [7]. Locke developed three important dimensions of job satisfaction. They are as follows:

- Job satisfaction is an emotional response to a job situation. As such, it cannot be seen; it can only be inferred.

- Job satisfaction is often determined by how well outcomes meet or exceed expectations. For example, if organizational participants feel that they are working much harder than other in the department but are receiving fewer rewards, they will probably have a negative attitude toward the work, the boss and/or coworkers and they will be dissatisfied. On the other hand, if they feel that they are being treated very well and are being paid equitably, they are likely to have a positive attitude toward the job, and then they will be job satisfied.

- Job satisfaction represents several related attitudes. [8].

\subsection{Factors affecting job satisfaction}

Job satisfaction is concerned with several attitudes including attitudes about the job characteristics, compensation and benefits, status, social security, advancement opportunities, technological challenges and respect. [9]. The most widely used factors of job satisfaction are work, pay, promotion, supervision and coworkers [10].

The factors conducive to job satisfaction are: pay, work, environment, co-workers. [11]. Similarly, "having adequate work equipment, resources, and training opportunities and an equitable workload distribution - also significantly and positively affect employee job satisfaction." [12].

Employee's satisfaction of job is a mixture of several factors. These factors are- Working condition, freedom or autonomy, job security, relationship with co-workers, relationship with superior, salary, career advancement and growth. These factors are described below:

Working condition: As employee spends most of the time in an organization, it is essential for organization to introduce and maintain proper working conditions. Organization should provide its employee's all the necessary resources and update all the information essential to do a job. This will help employees to accomplish tasks successfully and which indeed contribute to job satisfaction.

Freedom or autonomy: Autonomy refers to the degree of freedom that workers have in their work. It means the level of control employees have timing and scheduling their work activities.

Job security: Job security is another very important factor that may affect employee job satisfaction. Employees will often feel more secure if they believe they will not get fired.

Relationship with co-workers: Every employee seeks to be treated with respect by those they work with. If employees are in touch with supportive colleagues or peer they can do their performance in a better and comfortable way.

Relationship with superior: Employees need to know their superior's door is always open for them to discuss any issues to do their jobs effectively.

Salary: One of the most important factors that affect job satisfaction is salary. Companies need to have a instrument in place to assess employee performance and provide salary increases. Prospect to earn special incentives, such as bonuses, extra paid time off or vacations also bring stimulation and higher job satisfaction.

Career advancement or growth: If employees see a path available to move up the position in the company they would be more satisfied with their existing job. Organization can persuade employees to learn sophisticated skills or to demonstrate them what they need to in order to be on a path to progression inside the organization. 


\section{Methodology}

The methodology employed in attaining information about job satisfaction in telecommunication companies through a survey. The survey questionnaire is designed and distributed to targeted respondents. Questionnaire is designed into two parts. First part is taking consideration in demographical factor of respondents. The second part of the questionnaire is required the respondents to rate various factors that affects job satisfaction into five pre-defined level scale. These scales are as follows: $1=$ Strongly dissatisfied, $2=$ Dissatisfied, 3 = Neutral, 4 = Satisfied, 5 = Strongly satisfied.

Table 1: Factors that affect job satisfaction into five pre-defined level scale

\begin{tabular}{|l|l|l|l|l|l|l|}
\hline & & 1 & 2 & 3 & 4 & 5 \\
\hline 1 & Nature of work & & & & & \\
\hline 2 & Promotional opportunity & & & & & \\
\hline 3 & Relationship with colleagues & & & & & \\
\hline 4 & Relationship with superiors & & & & & \\
\hline 5 & Decision making authority & & & & & \\
\hline 6 & Level of freedom or authority & & & & & \\
\hline 7 & Salary & & & & & \\
\hline 8 & Work environment & & & & & \\
\hline 9 & Recreational activities & & & & & \\
\hline 10 & Reward system & & & & & \\
\hline
\end{tabular}

\section{Analysis And Findings}

This paper has taken a few important demographic information those indeed influence the customers regarding the selection or evaluation of the banking organization. Among those gender, income and age are of most important for this study. Most of the employees are male in gender category $(62.2 \%)$ and age (25-35) in age category. $34.1 \%$ employees earned a monthly income between TK 20,000-TK 40,000 and length of services of $39 \%$ employees are in between $1-5$ years.

\section{Analysis based on personal factors}

Gender: Study reveals that woman to man ratio is $4: 20$. Most of the male employees are dissatisfied with the promotion criteria compared to women.

Age: Age is an important factor to decide about job satisfaction. Age ranging between $36-45$ is more concerned about job security. Younger employees are given more emphasis on relationship with colleagues.

Salary: Employees whose salary below 40,000 are less satisfied with job as they desire for higher salary and study also shows that employee's salary above 50,000 are more satisfied with their job.

Length of service: It has been seen that job satisfaction level among officers level employee is somewhat below par as they wanted to show their competence to the higher level and demand promotion. It is observed that most of the employees put a lot of efforts in their work at the initial stage of their career.

\section{Analysis based on factors that affects job satisfaction}

Table 2: Factors affecting job satisfaction of employees

\begin{tabular}{|l|c|}
\hline \multicolumn{1}{|c|}{ Factors } & Mean \\
\hline Working condition & 60.6 \\
\hline Autonomy or freedom & 56.4 \\
\hline Job security & 61.4 \\
\hline Relationship with co-workers & 62.4 \\
\hline Relationship with superior & 56.8 \\
\hline Promotion & 59.6 \\
\hline Pay & 61.2 \\
\hline
\end{tabular}

In terms of level on work conditions, the study found that 43 respondent's perceived atmosphere to be "Neither satisfied nor dissatisfied". About 28 respondents perceived the work conditions to be "satisfied", while 17 respondents perceived work conditions as "dissatisfied". A few, 8 respondents rated the work conditions as "strongly dissatisfied" and "strongly satisfied" 4 . The mean score is 3.03.In terms of level of freedom, the study found that 49 respondent's perceived freedom to be "Neither satisfied nor dissatisfied". About 16 respondents perceived freedom to be "satisfied", While 24 respondents perceived work conditions as "dissatisfied". A few, 8 
respondents rated the work conditions as "strongly dissatisfied" and "strongly satisfied" 3 . The mean score is 2.82.In terms of job security; the study found that 23 respondents are "satisfied" while 16 are dissatisfied. A few, 4 respondents are "strongly dissatisfied" and "strongly satisfied" 4. The mean score is 3.07. In case of relationship with co-workers, 18 respondents are "dissatisfied" where 26 respondents are "satisfied". About 3 respondents are "strongly dissatisfied" and 5 "strongly satisfied". The mean score is 3.12. In terms of relationship with superior, it is found that 16 respondents are "satisfied',24 respondents are "dissatisfied", About 4 respondents are strongly satisfied and 8 respondents are "strongly dissatisfied". The mean score is 2.84.In terms of promotion it is found that, 20 respondents are satisfied , 24 respondents are dissatisfied, Only a few of 3 and 4 of the respondents are "strongly dissatisfied" and "strongly satisfied". The mean score is 2.98.In terms of pay it is found that 24 respondents are "satisfied", 20 respondents "dissatisfied". , Only a few of 4 and 3 of the respondents are "strongly dissatisfied" and "strongly satisfied". The mean score is 3.06.

\section{Results}

This research focuses on the factors affecting employee job satisfaction in selected telecommunication company. The primary descriptive results for each factor are as follows:

- In general the results are positive. Most of the employees tend to be satisfied with their job.

- The factors that lead to highest satisfaction are working condition, job security and relationship with co-workers and pay.

- The factors that lead to lowest satisfaction are freedom, relationship with immediate supervisor and promotion.

\section{Recommendations \& Conclusion}

From the extensive study on telecommunication sectors in Bangladesh, it is revealed that employees are satisfied with some factors but there are also some factors that should be taking into consideration:

- Top level management should provide some sorts of autonomy and decision making power to their employees.

- Company should provide all the necessary resources (information, tools, equipments etc.) to the employees to perform their duties efficiently and effectively.

- Promotion structure should be rearranged. Manager should give more priorities on performance and efforts rather than on their personal characteristics.

- Manger should recognize the efforts of employees and appreciate their valuable performance towards organization.

The analysis of all the factors of the job satisfaction among the telecommunication sector of Bangladesh concludes that most of the employees working in are satisfied with their working condition, pay, and relationship with colleagues. The study reveals some factors that are point of high concern to employees regarding their satisfaction. These factors are job security, promotion, relationship with superiors. This study recommended that job satisfaction can affect employee's performance, confidence level, behavior which is vital for the success of an organization. This recommendation is not only applicable in telecommunication industries but also in other institutions. . As success of an organization depends mostly on the performance of employees so they need to be satisfied.

\section{References}

[1] Robbins, S.P.; Odendaal, A. and Roodt, G. Organisational Behaviour, Global and Southern African Perspectives. (Cape Town, Pearson Education, 2003).

[2] Price, J.L., Handbook of Organizational Measurement, International Journal of Manpower, 18, 1997, $303-558$

[3] Spector, P. E. . Industrial \& organizational psychology, 2nd ed.. (New York, 2000: John Wiley \& Sons.)

[4] Ellickson. M.C., \& Logsdon, K. Determinants of job satisfaction of municipal employees 31(3) [Electronic version]. Public Personnel Management, 2002, 343-358.

[5] A.H. Maslow, Motivation and Personality. (New York: Harper \& Row, 1954).

[6] Cranny, C. J.; Smith, P. C. and Stone, E. F., Job Satisfaction, (Lexington Books: New York, 1992).

[7] Locke, E.A. (1976), The Nature and Cause of Job Satisfaction, in M.D. Dunnette (ed.), Handbook of Industrial and Organizational Psychology, Rand McNally, Chicago: 1297-1349.

[8] Mitchell and Larson, People in Organizations, 3rd ed., (McGraw-Hill, New York,1987)

[9] Tella A., Ayeni CO., \& Popoola SO (2007). Work Motivation, job satisfaction and organizational commitment of Library personnel in Academic and Research Libraries in OYO State Nigeria. Practice of Library and philosophy. Available at: www.webpages.uidaho.edu/ mbolin/. Accessed on 23rd, March, 2009.

[10] Luthans F (2005). Organizational Behavior. 10th, ed. McGraw-Hill, International ed. USA.

[11] Robbins SP, Organizational Behavior: Contexts, Controversies, Applications; P. 125 (Prentice- Hall, USA, 1998).

[12] Ellickson MC, Logsdon K (2001). Determinants of job satisfaction of Municipal Government employees. State and Local government Review. 33(3):173-184. Available at: http://www.cviog.uga.edu/publications/slgr/2001/3b.pdf. Accessed on 23rd, March, 2009. 
Appendix-1

Personal profile of the respondents $(\mathrm{N}=82)$

\begin{tabular}{|c|c|c|c|c|c|}
\hline \multicolumn{2}{|c|}{ Profile } & Frequency & Percent & $\begin{array}{l}\text { Valid } \\
\text { percent }\end{array}$ & $\begin{array}{l}\text { Cumulative } \\
\text { Percentage }\end{array}$ \\
\hline Sex & $\begin{array}{l}\text { Male } \\
\text { Female }\end{array}$ & $\begin{array}{l}51 \\
31\end{array}$ & $\begin{array}{l}62.2 \\
37.8\end{array}$ & $\begin{array}{l}62.2 \\
37.8\end{array}$ & $\begin{array}{l}62.2 \\
100.0\end{array}$ \\
\hline Age & $\begin{array}{l}25-35 \\
36-45 \\
46-55 \\
56-\text { above }\end{array}$ & $\begin{array}{l}28 \\
24 \\
18 \\
12\end{array}$ & $\begin{array}{l}34.1 \\
29.3 \\
22 \\
14.6\end{array}$ & $\begin{array}{l}34.1 \\
29.3 \\
22 \\
14.6\end{array}$ & $\begin{array}{l}34.1 \\
63.4 \\
85.5 \\
100.0\end{array}$ \\
\hline Salary & $\begin{array}{l}\text { Below } 20000 \\
20000-40000 \\
40000-60000 \\
60000-80000 \\
80000 \text { or more }\end{array}$ & $\begin{array}{l}26 \\
28 \\
12 \\
10 \\
6\end{array}$ & $\begin{array}{l}31.7 \\
34.1 \\
14.6 \\
12.2 \\
7.3\end{array}$ & $\begin{array}{l}31.7 \\
34.1 \\
14.6 \\
12.2 \\
7.3\end{array}$ & $\begin{array}{l}31.7 \\
65.9 \\
80.5 \\
92.7 \\
100.0\end{array}$ \\
\hline \multicolumn{2}{|c|}{$\begin{array}{cc}\text { Length of service } & 1-5 \\
& 5-10 \\
& 10-15 \\
& 15-\text { Above }\end{array}$} & $\begin{array}{l}32 \\
26 \\
14 \\
10\end{array}$ & $\begin{array}{l}39 \\
31.7 \\
17 \\
12.2\end{array}$ & $\begin{array}{l}39 \\
31.7 \\
17 \\
12.2\end{array}$ & $\begin{array}{l}39 \\
70.8 \\
87.8 \\
100.0\end{array}$ \\
\hline
\end{tabular}

\section{Appedix-2}

1. Level of working condition

\begin{tabular}{|lllll|}
\hline Satisfaction Level & $\begin{array}{c}\text { Value } \\
\text { of } \mathrm{X}\end{array}$ & Frequency & $\mathrm{d}=\mathrm{X}-\mathrm{A}$ & $\mathrm{fd}$ \\
Strongly dissatisfied & 1 & 8 & -2 & -16 \\
Dissatisfied & 2 & 24 & -1 & -24 \\
Neutral & 3 & 49 & 0 & 0 \\
Satisfied & 4 & 16 & 1 & 16 \\
Strongly satisfied & 5 & 3 & 2 & 6 \\
\hline & & $\sum \mathrm{f}=100$ & & $\sum \mathrm{fd}=-18$ \\
\hline
\end{tabular}

$\mathrm{X}=\mathrm{A}+(\Sigma \mathrm{fd} / \Sigma \mathrm{f})$

$=3+(-18 / 100)=2.82$

$=2.82 \times 20$

$=56.4 \%$

2. Level of autonomy or freedom

\begin{tabular}{|c|c|c|c|c|}
\hline $\begin{array}{l}\text { Satisfaction } \\
\text { Level }\end{array}$ & $\begin{array}{c}\text { Value of } \\
\mathrm{X}\end{array}$ & Frequency & $d=X-A$ & $\mathrm{fd}$ \\
\hline Strongly dissatisfied & 1 & 8 & -2 & -16 \\
\hline Dissatisfied & 2 & 17 & -1 & -17 \\
\hline Neutral & 3 & 43 & 0 & 0 \\
\hline Satisfied & 4 & 28 & 1 & 28 \\
\hline Strongly satisfied & 5 & 4 & 2 & 8 \\
\hline & & $\sum \mathrm{f}=100$ & & $\sum \mathrm{fd}=3$ \\
\hline
\end{tabular}

$\mathrm{X}=\mathrm{A}+(\Sigma \mathrm{fd} / \Sigma \mathrm{f})$

$=3+(3 / 100)=3.03$ 
$=3.03 \times 20$

$=60.6 \%$

3. Level of job security

\begin{tabular}{|c|c|c|c|c|}
\hline $\begin{array}{l}\text { Satisfaction } \\
\text { Level }\end{array}$ & Value of X & Frequency & $d=X-A$ & $\mathrm{fd}$ \\
\hline $\begin{array}{l}\text { Strongly } \\
\text { dissatisfied }\end{array}$ & 1 & 8 & -2 & -16 \\
\hline Dissatisfied & 2 & 24 & -1 & -24 \\
\hline Neutral & 3 & 48 & 0 & 0 \\
\hline Satisfied & 4 & 16 & 1 & 16 \\
\hline $\begin{array}{l}\text { Strongly } \\
\text { satisfied }\end{array}$ & 5 & 4 & 2 & 8 \\
\hline & & $\sum \mathrm{f}=100$ & & $\sum \mathrm{fd}=-16$ \\
\hline
\end{tabular}

$=3+(-16 / 100)=-2.84$

$=2.84 \times 20$

$=-56.8$

4. Level of relationship with co-workers

\begin{tabular}{|lllll|}
\hline $\begin{array}{l}\text { Satisfaction } \\
\text { Level }\end{array}$ & Value of X & Frequency & $\mathrm{d}=\mathrm{X}-\mathrm{A}$ & $\mathrm{fd}$ \\
$\begin{array}{l}\text { Strongly } \\
\text { dissatisfied }\end{array}$ & 1 & 4 & -2 & -8 \\
Dissatisfied & 2 & 16 & -1 & -16 \\
Neutral & 3 & 53 & 0 & 0 \\
Satisfied & 4 & 23 & 1 & 23 \\
$\begin{array}{l}\text { Strongly } \\
\text { satisfied }\end{array}$ & 5 & 4 & 2 & 8 \\
\hline \multicolumn{2}{|l}{} & & & \\
\hline & & $\sum \mathrm{f}=100$ & & $\sum \mathrm{fd}=7$ \\
\hline
\end{tabular}

$\mathrm{X}=\mathrm{A}+(\Sigma \mathrm{fd} / \Sigma \mathrm{f})$

$=3+(7 / 100)=3.07$

$=3.07 \times 20$

$=61.4 \%$

5. Level of relationship with superior

\begin{tabular}{|c|c|c|c|c|}
\hline $\begin{array}{l}\text { Satisfaction } \\
\text { Level }\end{array}$ & Value of $X$ & Frequency & $\mathrm{d}=\mathrm{X}-\mathrm{A}$ & $\mathrm{fd}$ \\
\hline $\begin{array}{l}\text { Strongly } \\
\text { dissatisfied }\end{array}$ & 1 & 3 & -2 & -6 \\
\hline Dissatisfied & 2 & 20 & -1 & -20 \\
\hline Neutral & 3 & 49 & 0 & 0 \\
\hline Satisfied & 4 & 24 & 1 & 24 \\
\hline $\begin{array}{l}\text { Strongly } \\
\text { satisfied }\end{array}$ & 5 & 4 & 2 & 8 \\
\hline & & $\sum \mathrm{f}=100$ & & $\sum \mathrm{fd}=$ \\
\hline
\end{tabular}

$\mathrm{X}=\mathrm{A}+(\Sigma \mathrm{fd} / \Sigma \mathrm{f})$

$=3+(12 / 100)=3$ 
$=3.12 \times 20$

$=62.4 \%$

6. Level on promotion

\begin{tabular}{|lllll|}
\hline $\begin{array}{l}\text { Satisfaction } \\
\text { Level }\end{array}$ & Value of X & Frequency & $\mathrm{d}=\mathrm{X}-\mathrm{A}$ & $\mathrm{fd}$ \\
$\begin{array}{l}\text { Strongly } \\
\text { dissatisfied }\end{array}$ & 1 & 3 & -2 & -6 \\
Dissatisfied & 2 & 18 & -1 & -18 \\
Neutral & 3 & 48 & 0 & 0 \\
Satisfied & 4 & 26 & 1 & 26 \\
Strongly & 5 & 5 & 2 & 10 \\
satisfied & \multicolumn{2}{|l|}{} & \multicolumn{2}{l|}{} \\
\hline
\end{tabular}

$\mathrm{X}=\mathrm{A}+(\Sigma \mathrm{fd} / \Sigma \mathrm{f})$

$=3+(-2 / 100)=2.98$

$=2.98 \times 20$

$=59.6 \%$

7. Level on pay

\begin{tabular}{|lllll|}
\hline $\begin{array}{l}\text { Satisfaction } \\
\text { Level }\end{array}$ & Value of X & Frequency & $\mathrm{d}=\mathrm{X}-\mathrm{A}$ & $\mathrm{fd}$ \\
$\begin{array}{l}\text { Strongly } \\
\text { dissatisfied }\end{array}$ & 1 & 3 & -2 & -6 \\
Dissatisfied & 2 & & & \\
Neutral & 3 & 24 & -1 & -24 \\
Satisfied & 4 & 49 & 0 & 0 \\
Strongly & 5 & 20 & 1 & 20 \\
satisfied & 4 & 2 & 8 \\
\hline & & & & \\
\hline
\end{tabular}

$\mathrm{X}=\mathrm{A}+(\Sigma \mathrm{fd} / \Sigma \mathrm{f})$

$=3+(6 / 100)=3.06$

$=3.06 \times 20$

$=61.2 \%$ 